Article

\title{
The Inhibitory Effects and Positive Contributions of Live Foods on Protease Activities of Meagre, Argyrosomus regius (Asso 1801), Larvae In Vitro Assay
}

\author{
Gürkan Diken ${ }^{1, *}$, Orhan Demir ${ }^{1}$ and Mehmet $\mathrm{Naz}^{2}$ \\ 1 Faculty of Eğirdir Fisheries, Isparta University of Applied Sciences, Isparta 32260, Turkey; \\ orhandemir@isparta.edu.tr \\ 2 Marine Science and Technology Faculty, Iskenderun Technical University, İskenderun, Hatay 31200, Turkey; \\ mehmetnaz76@gmail.com \\ * Correspondence: gurkandiken@isparta.edu.tr
}

Received: 5 November 2018; Accepted: 21 January 2019; Published: 4 February 2019

\begin{abstract}
The determination of exogenous enzyme contributions in live food is important in larval feeding. This study investigated the potential inhibitory effects and contributions of live foods used from 3 to 32 days after hatching (DAH) on protease activities of meagre (Argyrosomus regius) larvae (ML), using in vitro techniques. Enriched rotifer (R), Artemia nauplii (A0), and Artemia metanauplii (A1) were tested. The highest values of protease activities of ML were determined to occur at 7 DAH for the years 2013 and 2014. The lowest values were observed at 15 DAH in 2013 and at $20 \mathrm{DAH}$ in 2014. Protease activities of $\mathrm{R}, \mathrm{A} 0$, and A1 were $21.76 \pm 0.31,36.00 \pm 1.48-29.33 \pm 0.93$, and $416.44 \pm 19.7-403.53 \pm 11.85 \mathrm{U} / \mathrm{mg}$ protein, respectively $(p<0.05)$. The highest inhibitions of live foods were observed at $7 \mathrm{DAH}$. This situation was related to the inadequacy of protease contributions of live feeds, despite the highest protease value of larvae at $7 \mathrm{DAH}(p<0.05)$. The positive contributions of A1 live food on the protease activities of ML were significant $(p<0.05)$. The inhibitory effects and positive contributions of live foods on the survival and growth rates of ML should be taken into account for future studies considering the larvae of ML and other marine fish.
\end{abstract}

Keywords: meagre; Argyrosomus regius; protease activity; inhibitions; live food; in vitro

\section{Introduction}

Providing sufficient amounts of nutrients to marine fish species whose initial feeds are 35-100 $\mu \mathrm{m}$ is an important and controversial subject of larval nutrition that affects the development of rearing [1-3]. Although microdiets have been used with satisfactory results in fish species such as salmonid fishes and African catfish (Clarias gariepinus) larvae, growth and survival rates observed were lower than those obtained in larvae fed on Artemia nauplii [4,5]. However, the larval stages of marine fish require live food organisms for optimal growth and survival. Cahu and Zambonino Infante indicated that the survival and growth of marine fish larvae fed solely on microdiet are known to be very poor, but supplementation with live foods usually results in a marked improvement [6]. To explain the success of live food over microdiets, some authors have shown that fish larvae had insufficient digestive enzyme capacity for the digestion of exogenous food [7-9]. However, additional information is needed to define the factors that influence the better use of live food by fish larvae when compared to microdiets. Therefore, recent studies have been focused on the contribution of digestive enzymes from Artemia and rotifers commonly used as the major food source in aquaculture [10,11]. García-Ortega et al. showed that the contribution of digestive enzymes from Artemia to the total digestion of food by catfish (Clarias gariepinus) larvae was less than $1 \%$ of the total amount of the proteolytic activity measured 
in the larval gut [11]. Some studies have demonstrated that proteases derived from live food had only a small contribution to the enzymatic activity measured in and seabass (Dicentrarchus labrax) and sardine (Sardinops melanotictus) larvae [10,12]. Despite the results of the above studies, some unresolved issues still exist concerning the contribution of exogenous enzymes of digestion. For a sustainable aquaculture, studies on the effects of live foods that support the protease activity of larvae in critical feeding periods are key to understanding and solving nutritional problems. With this in mind, the inhibitory effects of the live foods used in larval feedings must be investigated in order to solve the nutritional problems. Studies carried out until now have focused on the changes in the biochemical compositions and enzymatic activities observed through the different developmental stages and the different periods, such as the enrichment and the starvation of live foods [13,14].

There are potential enzymatic differences associated with different live foods. Artemia, which is a feed source affected by environmental and seasonal effects, is commonly used as a live food source. However, in spite of its superiority as a feed source, the lack of copepods culture at the industrial level means that there may be differences in enzyme activities due to a lack of standardization-this represents an important problem when feeding live larvae [15-23]. It has been reported that external enzymes in live foods, especially in Artemia, help the larval digestion to activate the zymogens present in the larval gut [24-26]. It was previously determined that live foods did not promote enzyme production or secretion in the lumen of the intestine-it was deficiencies in the pancreatic and intestinal enzyme levels of the larvae fed by live food or microdiet-and that the contribution of the external enzyme is limited by the autolytic process of live food on the larval intestine [25,26]. It has also been understood that the contribution of external digestive enzymes to the total digestive capacity of larvae can be neglected in many species [26]. On the other hand, Artemia has been reported to activate endocrine factors that stimulate the endocrine response, accelerate the bombesin hormone affecting digestion, and increase the use of microdiets [25]. Due to these important determinations of live food feeding in larva culture, it is important to present practical applications in order to improve the status and traceability of live food feeding.

In this study and the other studies related to the production of meagre (Argyrosomus regius), which is an important species for the Mediterranean Basin, it was determined that the larvae developed rapidly [27-34]. This can be considered an important advantage for the feeding and culturing of meagre larvae. However, it is important to determine the changes in the ontogenetic and enzymatic activities of the larvae as well as larval development. In relation to this topic, there have also been studies dealing with the enzymatic changes of the meagre [31,33-36]. On the other hand, there is a lack of studies and an inadequacy of practical applications to evaluate the optimum potential of live food sources in terms of changes in larval development and enzymatic activities. Currently, a study on the inhibitory effects of live foods on protease activities of meagre larvae is not available. Studies carried out on this subject will help to provide more robust scientific evaluation as well as assist in industrial development.

Therefore, the aims of this research were (i) to evaluate the potential inhibitory effects of live foods commonly used in the routine feeding procedure of marine fish larvae, such as enriched rotifer (Brachionus plicatilis), Artemia nauplii, and Artemia metanauplii, on protease activities of meagre larvae using in vitro techniques, and (ii) to investigate the contribution of digestive proteases from live foods to the total digestion of food during critical larval stages of meagre larvae.

\section{Results}

In this study, results revealed the inhibition effects and the digestive protease contributions of live foods such as enriched rotifer, Artemia nauplii, and Artemia metanauplii on protease activities of meagre larvae from 3 to $32 \mathrm{DAH}$. Further, the growth parameters (the total length and wet weight values) of meagre larvae from 3 to $32 \mathrm{DAH}$ were determined. Total length and wet weight of meagre larvae values from $3 \mathrm{DAH}$ to $32 \mathrm{DAH}$ were $3.19 \pm 0.02-21.61 \pm 0.22 \mathrm{~mm}$ and $0.53 \pm 0.02-118.00 \pm 1.09 \mathrm{mg}$ in 2013 and $3.22 \pm 0.02-20.95 \pm 0.30 \mathrm{~mm}$ and $0.54 \pm 0.02-89.21 \pm 0.91 \mathrm{mg}$ in 2014, respectively (Figure 1). 


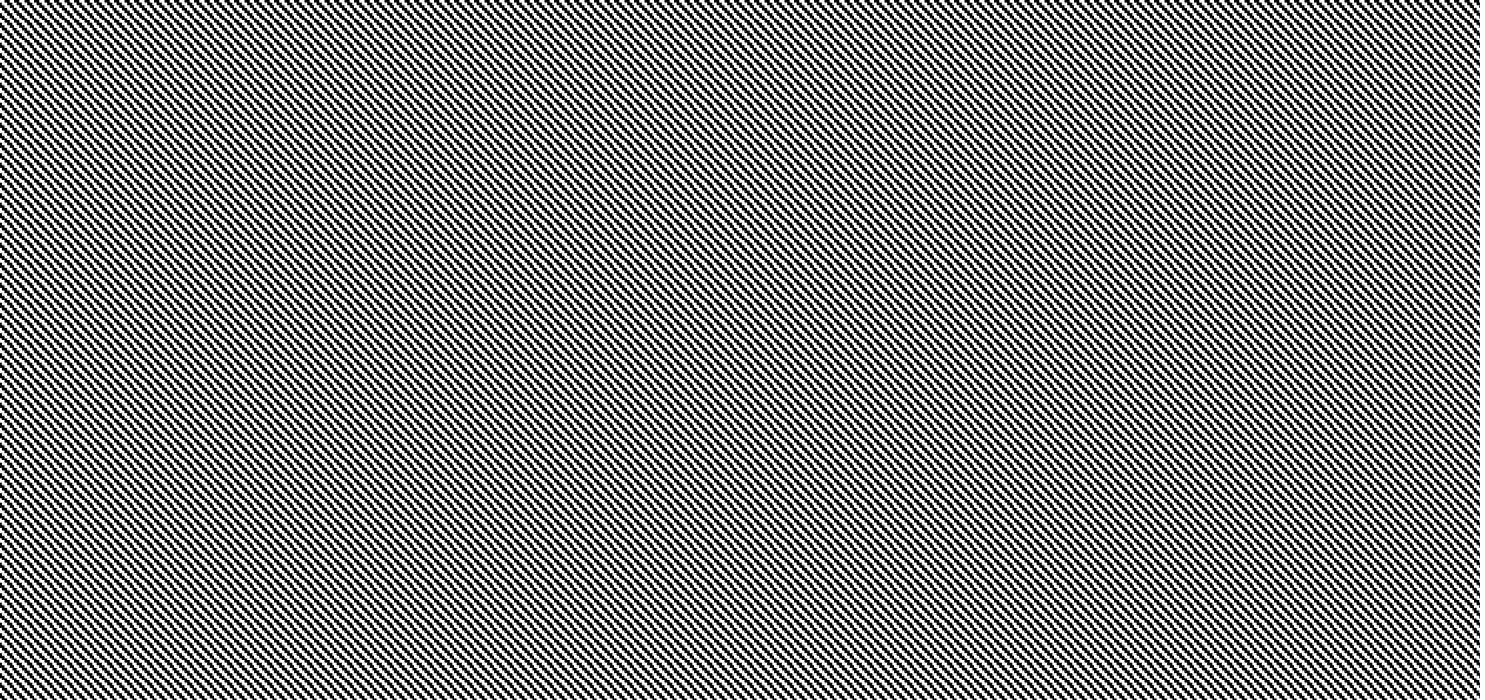

Figure 1. Total length and wet weight changes of meagre larvae ( $\mathrm{mm}$ and $\mathrm{mg}$, mean \pm standard error $(\mathrm{SE}), n=30)\left(0\right.$ to 15 days after hatching $(\mathrm{DAH})=364.8^{\circ} \mathrm{C}, 16$ to $32 \mathrm{DAH}=353.6^{\circ} \mathrm{C}, \Sigma{ }^{\circ} \mathrm{C}=718.6{ }^{\circ} \mathrm{C}$ in 2013 and 0 to $15 \mathrm{DAH}=348.6{ }^{\circ} \mathrm{C}, 16-32 \mathrm{DAH}=353.6^{\circ} \mathrm{C}, \Sigma^{\circ} \mathrm{C}=702.2{ }^{\circ} \mathrm{C}$ in 2014).

Figures 2 and 3 show protease activities of meagre larvae and inhibition values and contributions of live foods on protease activities of meagre larvae in 2013 and 2014, respectively. The differences observed in protease activities of meagre larvae from 3 to $32 \mathrm{DAH}$ were statistically significant $(p<0.05)$. The highest value of protease activities of meagre larvae at $7 \mathrm{DAH}$ was $211.21 \pm 12.56$ and $393.97 \pm 7.9 \mathrm{U} / \mathrm{mg}$ protein in 2013 and 2014, respectively. The lowest values of protease activities of meagre larvae in 2013 and 2014 were $5.95 \pm 0.60 \mathrm{U} / \mathrm{mg}$ protein at $15 \mathrm{DAH}$ and $9.64 \pm 1.25 \mathrm{U} / \mathrm{mg}$ protein at $20 \mathrm{DAH}$, respectively. Results revealed that the fluctuations in protease activities of the larvae feed of live food at the larva unit were sharper than those of the live food co-fed with the microdiet in the weaning unit.

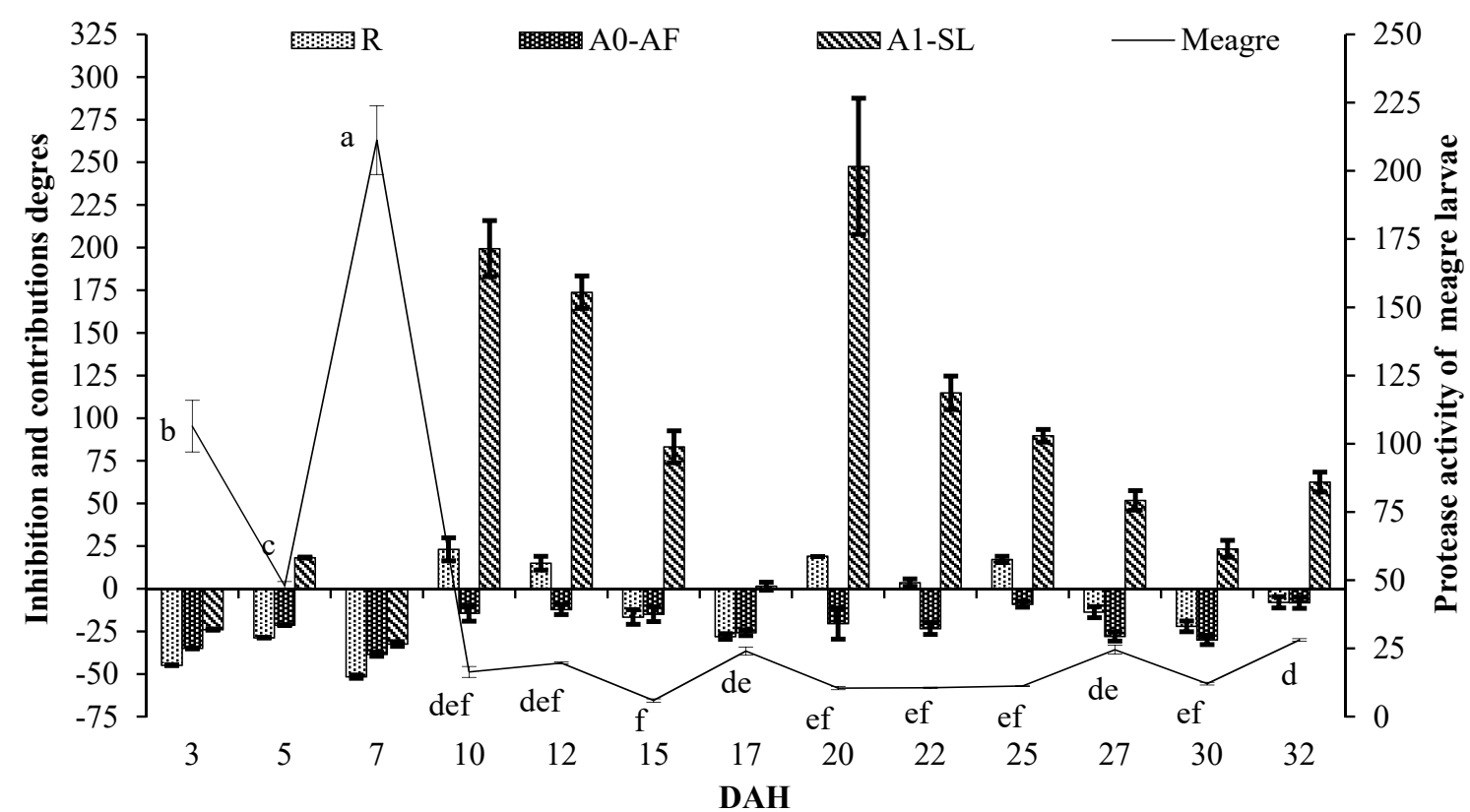

Figure 2. Protease activities of meagre larvae $(\mathrm{U} / \mathrm{mg}$ protein, mean $\pm \mathrm{SE})(p<0.05)$ and inhibitions and contributions of live foods on protease activities of meagre larvae in 2013 ( $\%$, mean \pm SE). Line-larva protease and bar-live food inhibition and contributions. 


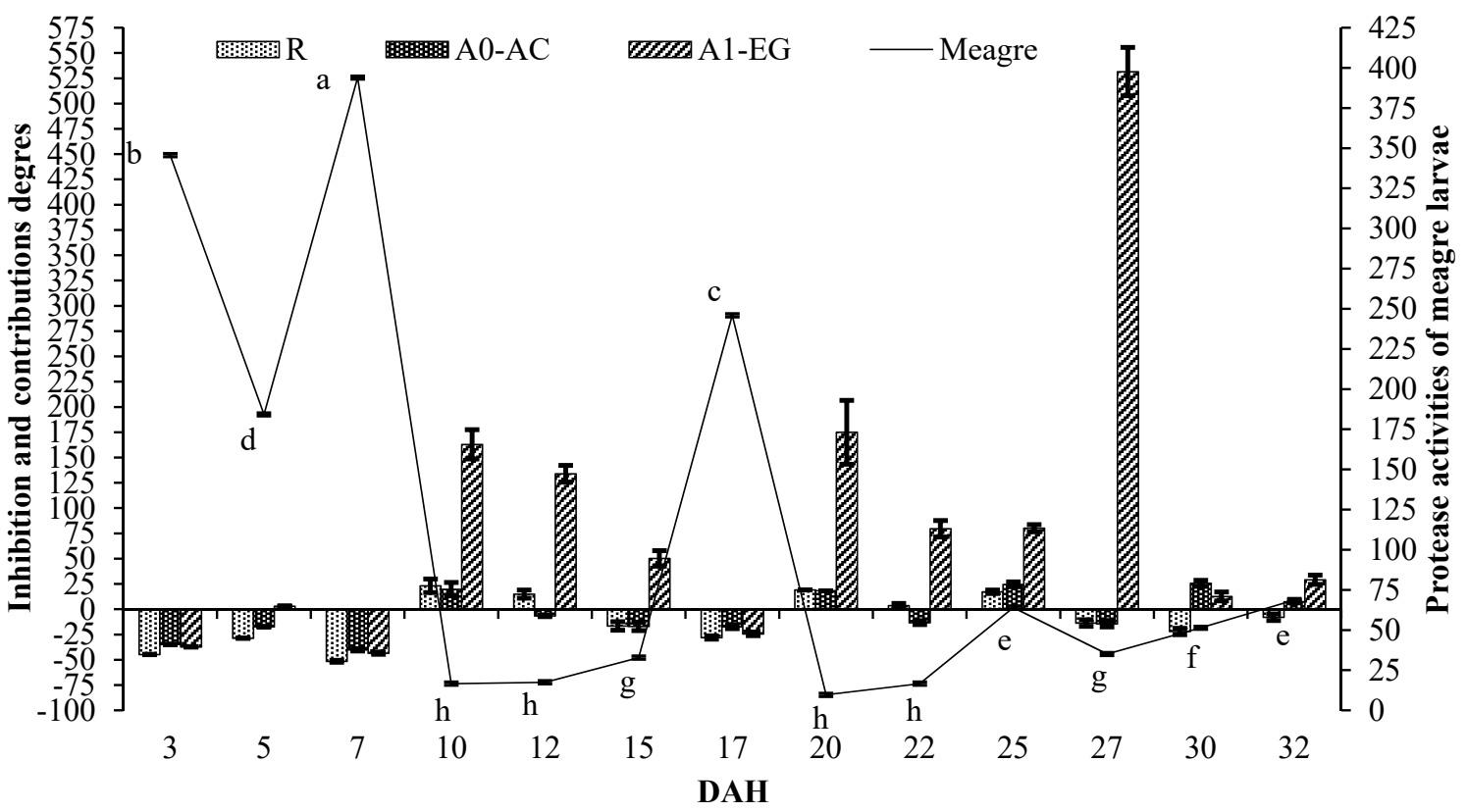

Figure 3. Protease activities of meagre larvae $(\mathrm{U} / \mathrm{mg}$ protein, mean $\pm \mathrm{SE})(p<0.05)$ and inhibitions and contributions of live foods on protease activities of meagre larvae in 2014 ( $\%$, mean \pm SE). Line-larva protease and bar-live food inhibition and contributions.

The changes observed in protease activities, inhibitions, and digestive protease contributions of live foods are given in Table 1. The differences observed in protease activities of live foods were statistically significant $(p<0.05)$. Protease activities of live foods tested in the current study such as enriched rotifer, Artemia nauplii, and Artemia metanauplii were $21.76 \pm 0.31$, $36.00 \pm 1.48$, and $29.33 \pm 0.93$, and $416.44 \pm 19.70$ and $403.53 \pm 11.85 \mathrm{U} / \mathrm{mg}$ protein, respectively. The differences observed between rotifer and Artemia nauplii were not statistically significant $(p>0.05)$. Moreover, the differences in Artemia metanauplii tested were not statistically significant $(p>0.05)$. The highest and lowest protease activities of live foods were found in Artemia metanauplii (A1-SL; $416.44 \pm 19.70 \mathrm{U} / \mathrm{mg}$ protein) and enriched rotifer ( $\mathrm{R} ; 21.76 \pm 0.31 \mathrm{U} / \mathrm{mg}$ protein), respectively.

According to the results of the inhibitory effects of live foods on protease activities of meagre larvae, the high inhibitions of protease activities were obtained when extracts were incubated in the presence of solutions prepared with live foods used in this study. The highest inhibitions of live foods tested in this study were observed in enriched rotifer ( $51.60 \pm 0.97 \%)$, Artemia nauplii (38.46 $\pm 1.23 \%$ and $40.29 \pm 1.20 \%$ ), and Artemia metanauplii ( $32.46 \pm 1.35 \%$ and $43.57 \pm 1.13 \%$ ) at $7 \mathrm{DAH}$.

On the other hand, the positive contributions of live foods such as enriched rotifer, Artemia nauplii, and Artemia metanauplii on protease activities of meagre larvae were determined during the sampling period. The highest contributions of enriched rotifer, Artemia nauplii, and Artemia metanauplii on protease activities of meagre larvae were $23.06 \pm 6.77 \%(10 \mathrm{DAH}), 24.52 \pm 2.44 \%(25 \mathrm{DAH})$, and $247.55 \pm 39.92 \%(20 \mathrm{DAH})-531.53 \pm 23.88 \%$ (27 DAH), respectively. Artemia metanauplii from 3 to $32 \mathrm{DAH}$ had positive contributions from $1.46 \pm 2.34 \%$ to $531.53 \pm 23.88 \%$ during the study, except for the inhibitions mentioned above. Digestive protease contributions of rotifer and Artemia nauplii were only identified in $10 \mathrm{DAH}$, including in the live food period, while the digestive protease contributions of Artemia metanauplii were observed in all feeding periods.

By contrast, different live food contributions were identified on different days of larval proteases, which were still low in 2014 ( $p<0.05)$. On the first day (3 DAH) when the mouth opened, inhibitory effects were observed in live food sources. In addition, attention had to be given to the effects of inhibition of live food in the first ten days (3-10 DAH). Even in this period, Artemia metanauplli inhibition effects were identified. 
Table 1. Protease activities of live foods and inhibitions and contributions of live foods on protease activities of meagre larvae.

\begin{tabular}{|c|c|c|c|c|c|}
\hline & \multirow{2}{*}{$\begin{array}{c}\text { Rotifer } \\
\text { R }\end{array}$} & \multicolumn{2}{|c|}{ Artemia nauplii } & \multicolumn{2}{|c|}{ Artemia metanauplii } \\
\hline & & A0-AF & A0-AC & A1-SL & A1-EG \\
\hline & \multicolumn{5}{|c|}{ Protease Activity (U/mg Protein, Means \pm SE) } \\
\hline & $21.76 \pm 0.31^{\mathrm{B}}$ & $36.00 \pm 1.48^{B}$ & $29.33 \pm 0.93^{B}$ & $416.44 \pm 19.70^{\mathrm{A}}$ & $403.53 \pm 11.85^{\mathrm{A}}$ \\
\hline & \multicolumn{5}{|c|}{ Inhibition and Contributions Degres $(\%$, Means \pm SE) } \\
\hline DAH & \multicolumn{5}{|c|}{ Larvae unit } \\
\hline 3 & $-44.87 \pm 0.23^{a}$ & $-35.02 \pm 0.27^{a b}$ & $-34.97 \pm 0.27^{\mathrm{a}}$ & $-23.98 \pm 0.32^{\mathrm{a}}$ & $-37.31 \pm 0.26^{\mathrm{a}}$ \\
\hline 5 & $-28.76 \pm 0.18^{b}$ & $-21.38 \pm 0.20$ cde & $-17.49 \pm 0.21^{b c}$ & $18.21 \pm 0.30^{b c}$ & $2.91 \pm 0.26^{\mathrm{bc}}$ \\
\hline 7 & $-51.60 \pm 0.97^{\mathrm{a}}$ & $-38.46 \pm 1.23^{a}$ & $-40.29 \pm 1.20^{\mathrm{a}}$ & $-32.46 \pm 1.35^{\mathrm{a}}$ & $-43.57 \pm 1.13^{a}$ \\
\hline 10 & $23.06 \pm 6.77^{\mathrm{f}}$ & $-14.41 \pm 4.71^{\text {def }}$ & $19.72 \pm 6.59^{\mathrm{f}}$ & $199.31 \pm 16.48^{g}$ & $162.94 \pm 14.48^{\mathrm{fg}}$ \\
\hline 12 & $14.91 \pm 4.01^{\mathrm{f}}$ & $-12.18 \pm 3.07$ ef & $-6.70 \pm 0.65^{d}$ & $173.80 \pm 9.57 \mathrm{~g}$ & $133.87 \pm 8.17^{f}$ \\
\hline 15 & $-16.64 \pm 4.27^{\mathrm{cd}}$ & $-14.99 \pm 4.36^{\mathrm{def}}$ & $-17.02 \pm 4.25^{b c}$ & $83.19 \pm 9.39$ ef & $50.17 \pm 7.70$ de \\
\hline & \multicolumn{5}{|c|}{ Weaning unit } \\
\hline 17 & $-28.10 \pm 1.66^{b}$ & $-25.80 \pm 1.71^{\mathrm{bcd}}$ & $-17.49 \pm 1.90^{b c}$ & $1.46 \pm 2.34^{\mathrm{ab}}$ & $-24.43 \pm 1.74 \mathrm{ab}$ \\
\hline 20 & $19.05 \pm 0.00^{\mathrm{f}}$ & $-20.42 \pm 9.14^{\mathrm{cdef}}$ & $18.30 \pm 0.00^{\mathrm{f}}$ & $247.55 \pm 39.92 \mathrm{~h}$ & $174.94 \pm 31.58 \mathrm{~g}$ \\
\hline 22 & $3.50 \pm 2.46^{\mathrm{e}}$ & $-23.37 \pm 3.50$ bcde & $-13.32 \pm 1.90^{\mathrm{cd}}$ & $114.80 \pm 9.82^{f}$ & $79.44 \pm 8.20^{e}$ \\
\hline 25 & $17.14 \pm 1.81^{\mathrm{f}}$ & $-9.11 \pm 1.78^{\mathrm{f}}$ & $24.52 \pm 2.44^{\mathrm{f}}$ & $89.64 \pm 3.71$ ef & $80.07 \pm 3.533^{e}$ \\
\hline 27 & $-13.74 \pm 3.26^{\mathrm{cd}}$ & $-27.98 \pm 2.72^{a b c}$ & $-14.46 \pm 3.24^{\mathrm{cd}}$ & $51.77 \pm 5.74$ cde & $531.53 \pm 23.88^{h}$ \\
\hline 30 & $-22.10 \pm 3.11 \mathrm{bc}$ & $-30.05 \pm 2.79 a b c$ & $-25.51 \pm 2.97^{b}$ & $23.34 \pm 4.92 \mathrm{bcd}$ & $12.54 \pm 4.49 \mathrm{bcd}$ \\
\hline 32 & $-8.00 \pm 3.30^{\mathrm{d}}$ & $-8.28 \pm 3.29^{\mathrm{f}}$ & $7.36 \pm 1.12{ }^{\mathrm{e}}$ & $62.46 \pm 5.83 \mathrm{de}$ & $29.11 \pm 4.63^{\mathrm{cd}}$ \\
\hline
\end{tabular}

Differences between different uppercase and lowercase letters in the same column (mean \pm SE) are significant $(p<0.05)$. The dark-colored columns show the values of the live foods in the period and the dark-colored numbers show the contributions of live foods.

\section{Discussion}

The purpose of in this present study was to determine the potential effects of live foods on protease activities of meagre larvae. The growth parameters (the total length and wet weight values) of meagre larvae from 3 to $32 \mathrm{DAH}$ were also determined in the study. The fluctuations in the protease activities of meagre larvae throughout the study were observed. Zambonino Infante and Cahu indicated that the decline observed in specific activities of enzymes is not due to a diminution in enzyme synthesis but is the result of an increase in tissue protein concentration [37].

Results showed that rotifer (B. plicatilis) protease activity level was lower than what Naz and Yúfera [19] identified, higher than Diken et al. [22], and similar to Haközü [20]. Additionally, Munilla-Moran et al. [7] showed that the rotifer had the lowest enzymatic activity compared to Artemia sp. and copepods. On the other hand, Artemia nauplii protease activity level was similar to Haközü [20] and Diken et al. [22]. Artemia metanauplii's protease activity level was lower than Diken et al. [22], higher than Haközü [20] and Diken et al. [23], and similar to Naz and Yúfera [19]. The differences between the protease activity of enriched rotifer and Artemia metanauplii and also between Artemia nauplii and Artemia metanauplii [18] agree with the results obtained in this study. Munilla-Moran et al. [7] indicated that the enzymatic activity of Artemia changed depending on the nutritional status and developmental stage. The results found on protease activities of live foods showed that the protease activity of Artemia metanauplii (A1-SL) was higher than those of rotifer and Artemia nauplii tested in the study, while A1-SL and A1-EG had similar protease activities. In addition, protease activity values of enriched rotifer and Artemia nauplii were similar to each other. These differences may be the result of the developmental status as previously mentioned by Naz [14] and Munilla-Moran et al. [7]. The results of this study and the results obtained by Naz [14] results revealed that the highest digestive protease contribution from live food to fish larvae used commonly in marine fish culture was provided by Artemia metanauplii. It has also been reported that the majority of Artemia eggs belong to a cysteine protease group affecting the contribution of the external enzyme, which is effective in the breakdown of proteins [38]. Yufera et al. [39] found that the foods of larvae in the first month after post-hatching were digested mainly by the action of alkaline proteases, and 
the $\mathrm{pH}$ of the gastrointestinal tract was alkaline. Therefore, in the fish in the larval stage that do not have a functional stomach, contributions of the digestive enzymes of Artemia reduced. Furthermore, the cysteine protease group is not active at alkaline $\mathrm{pH}$ [38]. It may be neutralized when such proteases are in contact with the alkaline contents of larval gut. Thus, these proteases might be meaningless to the fish larvae if the intestine is around a $\mathrm{pH}$ of 8.

Our results showed that live foods, such as enriched rotifer and Artemai nauplii, caused significant inhibitions on protease activities of meagre larvae. However, Artemia metanauplii had the lower inhibitions on the protease activities of larvae. Warner et al. [40] showed that encysted embryos and larvae of the brine shrimp Artemia franciscana contain a cysteine protease which represents over $90 \%$ of the protease activity in these organisms. It is known that cysteine proteases are active in acid but not in alkali mediums. Therefore, the inhibitions observed in live foods such as enriched rotifer and Artemai nauplii may be the result of cysteine protease, which represents over $90 \%$ of the protease activity found in Artemia embryos and larvae. The high positive contributions determined in live foods such as Artemia metanauplii may be the result of the decrease in cysteine proteases following the developmental status.

Cahu and Zambonino Infante [6] indicated that the survival and growth of marine fish larvae solely fed on microdiet are very poor, but supplementation with live foods usually results in a marked improvement. Results of this study along with those of Diken et al. [23] and Naz and Yúfera [19] showed that the contributions of Artemia metanauplii on protease activities of larvae were high, while the contributions of rotifer (B. plicatilis) and Artemia nauplii were low. Yúfera et al. [39] reported that during feeding gilthead seabream larvae, the contribution of rotifer on protease activity of larval intestines was not significant, thus supporting the situation of rotifer contributions in protease activities of meagre larvae. Therefore, contributions and inhibitions of live food on the digestive proteases of marine fish larvae should be taken into account during the optimization of feeding procedures.

According to current study, contributions of Artemia metanauplii on the protease activities of meagre larvae at 10-32 DAH were higher than that of gilthead seabream larvae at the 34-81 DAH weaning period [23] (Table 2). The current study showed that the contributions of Artemia metanauplii on the protease activities of meagre larvae at the end of the weaning at 30-32 DAH were lower than that of gilthead seabream at the beginning of the weaning at 34 DAH reported by Diken et al. [23]. The contributions of Artemia metanauplii on the protease activities of gilthead seabream at $34 \mathrm{DAH}$ were similar to that of meagre larvae at 15 and $25 \mathrm{DAH}$ and higher than that of meagre larvae at $17 \mathrm{DAH}$ [23]. The contributions of Artemia metanauplii on the protease activities of European seabass at the 35-67 DAH weaning period were higher than that of gilthead seabream larvae at the weaning period [23]. The contributions of Artemia metanauplii on the protease activities of European seabass at 35,46 , and 57 DAH were generally higher than that of meagre larvae at 10-32 DAH, except 10, 12 , and $20 \mathrm{DAH}$ [23]. The highest contributions of rotifer (B. plicatilis) on the protease activities of gilthead seabream were observed at $25 \mathrm{DAH}$ and were higher than the highest protease activities of meagre observed at 10 DAH [20]. Similarly, the highest contributions of Artemia nauplii on the protease activities of gilthead seabream were observed at $5 \mathrm{DAH}$ and were higher than the highest protease activities of meagre observed at $25 \mathrm{DAH}$ [20]. On the other hand, the highest contributions of Artemia metanauplii on the protease activities of gilthead seabream were observed at $25 \mathrm{DAH}$ and were higher than the highest protease activities of meagre observed at 20 and 27 DAH [20]. As a result, the protease activities of larvae and live foods should be evaluated based on the inhibitions and contributions of live food on the protease activity of larvae. It has been observed that there have been fluctuations in the inhibition and contribution of live food on the protease activities of larvae due to the growth status of the fast-growing larvae, especially at the pre-weaning of feeding period. Therefore, early feeding of fast-growing species with microdiets may increase the inadequate exogenous enzyme contributions of live food. In this context, the results of the study reveal the importance of species-specific studies. 
Table 2. Inhibitions and contributions of live foods on protease activities of marine fish larvae *.

\begin{tabular}{|c|c|c|c|c|c|c|c|}
\hline Species & & DAH & & Species & DAH & Species & DAH \\
\hline \multicolumn{8}{|c|}{ A. metanauplii (A1) } \\
\hline $\begin{array}{l}\text { A. regius } \\
\text { S. aurata }{ }^{1}\end{array}$ & $\begin{array}{c}10-32+ \\
34-81\end{array}$ & $\begin{array}{c}15,25 \sim \\
34 \sim\end{array}$ & $\begin{array}{c}30-32 / 17 \\
34+\end{array}$ & $\begin{array}{l}\text { S. } \text { aurata }^{1} \\
\text { D. } \text { labrax }^{1}\end{array}$ & $\begin{array}{c}34-81 \\
35-67+\end{array}$ & $\begin{array}{c}\text { A. regius } \\
\text { D. labrax }\end{array}$ & $\begin{array}{c}10,12,20+ \\
35,45,67\end{array}$ \\
\hline $\begin{array}{l}\text { A. regius } \\
\text { S. } \text { aurata }^{2}\end{array}$ & $\begin{array}{c}20,27 \\
25+\end{array}$ & & & & & & \\
\hline \multicolumn{4}{|c|}{ A. nauplii (A0) } & \multicolumn{4}{|c|}{ Rotifer (B. plicatilis) } \\
\hline $\begin{array}{l}\text { A. regius } \\
\text { S. aurata } 2\end{array}$ & $\begin{array}{l}25 \\
5+\end{array}$ & & & $\begin{array}{l}\text { A. regius } \\
\text { S. aurata } 2\end{array}$ & $\begin{array}{c}10 \\
25+\end{array}$ & & \\
\hline
\end{tabular}

In the current study, when Artemia digestive enzymes were compared to other live food digestive enzymes, the contributions of Artemia metanauplii on the protease activities of meagre larvae supported the idea that microdiet use may increase depending on the co-feeding of the Artemia and microdiet $[8,25,41]$. The positive effects of live food on the days when meagre larva protease activity is low supported the idea that contribution of the exogenous enzyme is important for feeding larvae [7]. Our results were supported by the research conducted on the contributions of rotifer (B. plicatilis) on sardine larvae [10], fluctuations in protease activity of larvae due to the decrease in the amount of Artemia feed in African catfish fish cultivation [11], and Artemia contributions to European seabass and gilthead seabream, [42-44].

\section{Materials and Methods}

This study was approved by the Local Ethical Committee of Animal Experiments of the Süleyman Demirel University (Ref. Number: B.08.6.YÖK.2.SD.0.05.0.07.00-22).

\subsection{Larval Rearing and Sampling}

The larval rearing and sampling stage of the present study was carried out at the EGEMAR Aquaculture Food Industry and Commercial Incorporated Company. The larval rearing and sampling protocol are shown in Table 3.

Table 3. Meagre larvae's rearing protocol.

\begin{tabular}{|c|c|}
\hline DAH * & Practice \\
\hline & $\begin{array}{l}\text { Hormone injection (GnRH; } 20 \mu \mathrm{g} \mathrm{kg}^{-1} \text { \% and } 10 \mu \mathrm{g} \mathrm{kg}{ }^{-1} \mathrm{o}^{7} \text { ) } \\
\text { Eggs incubation (conical fiberglass tank; } 23.6 \pm 0.5^{\circ} \mathrm{C} \text { temperature in } 2013 \text { and } 22.0 \pm 0.2 \\
\text { at temperature in 2014, respectively) }\end{array}$ \\
\hline $0-15$ & Larva tank (7 $\mathrm{m}^{3}$ ellipsoidal fiberglass tanks with black walls; 75-80 larvae/L) \\
\hline $15 / 16-32$ & $\begin{array}{l}\text { Weaning tank (raceway } 27 \text { and } 15 \mathrm{~m}^{3} \text { tank in } 2013 \text { and 2014, respectively and } \\
\text { 10-12 larvae/L) }\end{array}$ \\
\hline \multirow[t]{2}{*}{$0-32$} & $\begin{array}{l}\text { Sea water (sand, bag and UV filters; } 20.8-24.1^{\circ} \mathrm{C} \text { temperature, } 27.0-40.0 \mathrm{~g} / \mathrm{L} \text { salinity, } \\
8.4-14.4 \mathrm{mg} / \mathrm{L} \text { oxygen levels, } 7.5-7.9 \mathrm{pH} \text { in } 2013 \text { and } 20.8-22.2^{\circ} \mathrm{C} \text { temperature, } \\
27.0-40.0 \mathrm{~g} / \mathrm{L} \text { salinity, } 7.8-14.7 \mathrm{mg} / \mathrm{L} \text { oxygen } 7.7-8.1 \mathrm{pH} \text { levels in } 2014 \text {, respectively and } 18 \\
\text { h light and } 6 \mathrm{~h} \text { dark cycle) }\end{array}$ \\
\hline & Green water \\
\hline $3-15$ & $\begin{array}{l}\text { (Sanolife GWS; INVE Aquaculture, NV Hoogveld, 91 9200, Dendermonde, Belgium or } \\
\omega 3 \text { Algae }{ }^{\circledR} ; \text { Bernaqua, NV Hagelberg, } 3 \text { B-2250, Olen, Belgium in } 2013 \text { and Nannochloropsis } \\
\text { occulata in 2014, respectively) }\end{array}$ \\
\hline $16-26$ & Sanolife GWS in 2013 and Nannochloropsis occulata in 2014. \\
\hline
\end{tabular}


Table 3. Cont.

\begin{tabular}{|c|c|}
\hline DAH * & Practice \\
\hline & Live food \\
\hline $3-9$ and $3-8$ & $\begin{array}{l}\text { Rotifer, Brachionus plicatilis } \\
\text { Culture } 25^{\circ} \mathrm{C} \text { temperature and } 28 \mathrm{~g} / \mathrm{L} \text { salinity (Algamac Protein Plus; Aquafaune } \\
\text { Bio-Marine Inc. Hawthorne USA and Sparkle; INVE Aquaculture) } \\
\text { Enrich } 26^{\circ} \mathrm{C} \text { temperature and } 28 \mathrm{~g} / \mathrm{L} \text { salinity (Spresso; INVE Aquaculture) } \\
10-15 \text { prey/mL enriched rotifer (R) in } 2013 \text { and } 2014\end{array}$ \\
\hline $6-11$ and $7-11$ & $\begin{array}{l}\text { Artemia nauplii (AF 480; INVE Aquaculture and Artemia Cysts in } 2013 \text { and Vinh Chau-Bac } \\
\text { Lieu Artemia Co. in 2014, respectively) } \\
\text { Culture } 29^{\circ} \mathrm{C} \text { temperature and } 28 \mathrm{~g} / \mathrm{L} \text { salinty } \\
2-4 \text { prey/mL in } 2013 \text { and } 4-6 \text { prey/mL in } 2014 \text { Artemia nauplii (A0), respectively }\end{array}$ \\
\hline \multirow[t]{2}{*}{$10-32$} & $\begin{array}{l}\text { Artemia metanaupli (Artemia EG; Salt Lake Artemia Great Salt Lake Brine Shrimp } \\
\text { Cooperative, Inc.) in } 2013 \text { and Artemia (SepArt EG; Aquaculture Salt Lake City Utah/USA } \\
\text { in 2014). } \\
\text { Culture } 29{ }^{\circ} \mathrm{C} \text { temperature and } 28 \mathrm{~g} / \mathrm{L} \text { salinty } \\
\text { Enrich } 24 \mathrm{~h}, 26^{\circ} \mathrm{C} \text { temperature and } 28 \mathrm{~g} / \mathrm{L} \text { salinity (Algamac } 3050 \text {; Aquafaune Bio-Marine } \\
\text { Inc., or Red Papper; Bernaqua, or Spresso; INVE Aquaculture in } 2013 \text { and Spresso; INVE } \\
\text { Aquaculture in 2014). } \\
1.5-6 \text { prey/mL in } 2013 \text { and } 1.5-5 \text { prey } / \mathrm{mL} \text { in } 2014 \text { enriched Artemia (A1), respectively }\end{array}$ \\
\hline & Microdiets \\
\hline $16 / 17-32$ & 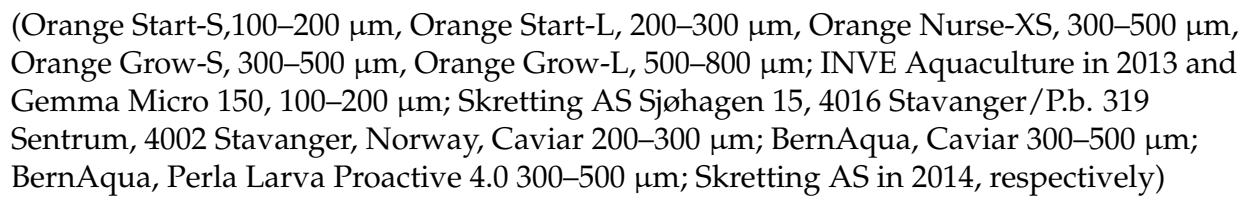 \\
\hline \multicolumn{2}{|l|}{ Sampling } \\
\hline $3-32$ & Before the morning feeding and stored in liquid nitrogen $\left(-196{ }^{\circ} \mathrm{C}\right)$ \\
\hline
\end{tabular}

\subsection{Analytical Methods}

\subsubsection{Extracts of Larvae}

The samples were rinsed in distilled water after thawing, and then the extracts of whole larvae were homogenized and centrifuged $\left(16,000 \times g, 30 \min 4{ }^{\circ} \mathrm{C}\right)$.

\subsubsection{Extracts of Live Foods}

Five live foods enriched rotifer (B. plicatilis; R), Artemia nauplii (AF 480, INVE Aquaculture; A0-AF), Artemia nauplii (Artemia Cysts, Vinh Chau-Bac Lieu Artemia Co.Op; A0-AC), Artemia metanauplii (EG, Salt Lake Artemia Great Salt Lake Brine Shrimp Cooperative, Inc.; A1-SL), and Artemia metanauplii (EG, INVE Aquaculture Salt Lake City Utah/USA; A1-EG) were tested with in vitro techniques in this study. Extracts of live foods prepared by homogenization $(100 \mathrm{mg} / \mathrm{mL}$ in distilled water) followed by centrifugation $(15,000 \times g, 10 \mathrm{~min})$ were used in protease inhibition analyses.

\subsubsection{Determination of Protease Activities of Larvae and Live Foods}

The total protease activities of meagre larvae and live foods were measured according to Walter [45]. Casein $(10 \mathrm{mg} / \mathrm{mL})$ in $50 \mathrm{mM}$ Tris- $\mathrm{HCl}$ buffer at $\mathrm{pH} 8.5$ was used as the substrate. The mixtures including extracts of larvae-substrate and live food-substrate were incubated, and then the reaction was stopped by the addition of $500 \mu \mathrm{L}$ trichloroaceticacid (TCA) $(120 \mathrm{~g} / \mathrm{L})$. One unit of enzyme activity was defined as $1 \mu \mathrm{g}$ of tyrosine released per minute. The soluble protein concentrations of meagre larvae and live foods were determined according to Bradford [46]. 


\subsubsection{Effects of Live Foods on Protease Activities of Larvae}

The inhibitory effects of live foods on protease activities of meagre larvae were determined by measuring the reduction in the protease activity of extracts using a modification of the method described by García-Carreño [47]. The method is based on the measurement of residual protease activity remaining after pre-incubation with live foods such as enriched rotifer, Artemia nauplii, and Artemia metanauplii.

\subsubsection{Statistical Methods}

Fish total length and wet weight were calculated and were given on as mean \pm standard error (SE). The experimental data (protease activities of meagre larvae and inhibitions and contributions of live foods on protease activities of meagre larvae) were subjected to one-way ANOVA and mean \pm SE differences were made by Duncan test at $p=0.05$ content level using SPSS software statistical package [48]. All measurements were carried out in triplicates.

\section{Conclusions}

The present study provides information about the potential effects of live foods used in the feeding of meagre larvae. When such data become available, live foods will serve as the replacement of live foods with microdiets for sustainable aquaculture. The protease contributions of live foods Artemia metanauplii tested in the study were higher than those of rotifer (B. plicatilis) and Artemia nauplii. The inhibitory effects and positive contributions of live foods used in the routine feeding protocols on survival and growth rates of meagre larvae should be taken into account in future studies. Further, cysteine protease activities of Artemia sp. should be investigated to provide the higher growth and survival ratio from the feeding protocols used in marine fish larvae.

The results of in this study reveal the importance of monitoring the enzyme activities of live food sources. It also supports the importance of monitoring the enzyme contribution and inhibitory effects of live feed food sources. The results give clues depending on the species cultivated for protocol assessments and preference of inert diets and co-feeding on live food during weaning. In this context, larval rearing is also contributing to the protocol arrangements. As a result, this practical application supports hatchery management for the traceability of live foods.

Author Contributions: All authors have contributed to the methodology, validation, investigation, data curation, manuscript writing, reviewing and editing. G.D. and O.D. have been in charge of the project administration and funding acquisition. G.D. and M.N. have carried out the formal analysis of the manuscript. G.D. and M.N. prepared the original draft.

Funding: This research was funded by the Unit of Scientific Research Projects from the Suleyman Demirel University; project no. SDÜBAP 3453-D2-13.

Acknowledgments: This study was supported by the Unit of Scientific Research Projects Suleyman Demirel University (Gürkan Diken's PhD thesis project no. SDÜBAP 3453-D2-13). I would like to thank to Metin Neke and Doğan Neke with the hatchery staff from EGEMAR that support the research.

Conflicts of Interest: The authors declare no conflict of interest.

\section{References}

1. Rainuzzo, J.R.; Retain, K.I.; Olsen, Y. The signifinance of lipids at early stages of marine fish: A Review. Aquaculture 1997, 155, 103-115. [CrossRef]

2. Palmtag, M.R.; Faulk, C.K.; Holt, G.J. Highly unsaturated fatty acid composition of rotifers (Brachionus plicatilis) and Artemia fed various enrichments. J. World Aquacult. Soc. 2006, 37, 126-131. [CrossRef]

3. Tucker, J.W., Jr. Marine Fish. In Aquaculture Farming Aquatic Animals and Plant, 2nd ed.; Lucas, J.S., Southgate, P.C., Eds.; Wiley-Blackwell: Chichester, UK, 2012; pp. 384-444.

4. Uys, W.; Hecht, T. Evaluation and preparation of an optimal dry feed for the primary nursing of Clarias gariepinus larvae (Piscess: Claridae). Aquaculture 1985, 47, 173-183. [CrossRef] 
5. Appelbaum, S.; Van Damme, P. The feasibility of using exclusively artificial dry feed for rearing of Israeli Clarias gariepinus (Burchell, 1882) larvae and fry. J. Appl. Ichthyol. 1998, 4, 105-110. [CrossRef]

6. Cahu, C.L.; Infante, J.Z. Early weaning of sea bass (Dicentrarchus labrax) larvae with a compound diet: Effect on digestive enzymes. Comp. Biochem. Physiol. Part A Physiol. 1994, 109, 213-222. [CrossRef]

7. Munilla-Moran, R.; Starch, J.R.; Barbout, A. The role of exogenous enzymes in digestion in cultured turbot larvae (Scophthalmus maximus). Aquaculture 1990, 88, 337-350. [CrossRef]

8. Kolkovski, S.; Tandler, A.; Kissil, W.G.; Gertlez, A. The effect of dietary exogenous digestive enzymes on ingestion, assimilation, growth and survival of gilthead seabream (Sparus aurata, L.) larvae. Fish Physiol. Biochem. 1993, 12, 203-209. [CrossRef] [PubMed]

9. Kolkovski, S.; Kowen, W.; Tandler, A. The mode of action of Artemia in enhancing utilisation of microdiet by gilthead seabream Sparus aurata larvae. Aquaculture 1997, 155, 193-205. [CrossRef]

10. Kurokawa, T.; Shiraishi, M.; Suzuki, T. Quantification of exogenous protease derived from zooplankton in the intestine of Japanese sardine Sardinops melanotictus larvae. Aquaculture 1998, 161, 491-499. [CrossRef]

11. García-Ortega, A.; Verreth, J.; Segner, H. Post-prandial protease activity in the digestive tract of African catfish Clarias gariepinus larvae fed decapsulated cysts of Artemia. Fish Physiol. Biochem. 2000, 22, 237-244. [CrossRef]

12. Cahu, C.L.; Zambonino, I.J.L.; Le Gall, M.M.; Quazuguel, P. Early weaning of seabass: Are digestive enzymes limiting. In Larvi'95-Fish and Shellfish Larviculture Symposium; Lavens, P., Jaspers, E., Roelants, I., Eds.; European Aquaculture Society Special Publication: Gent, Belgium, 1995; pp. 268-271.

13. García-Ortega, A.; Verreth, J.; Coutteau, P.; Segner, H.; Huisman, E.A.; Sorgeloos, P. Biochemical and enzymatic characterization of decapsulated cysts and nauplii of the brine shrimp Artemia at different developmental stages. Aquaculture 1998, 161, 501-514. [CrossRef]

14. Naz, M. The changes in the biochemical compositions and enzymatic activities of rotifer (Branchionus plicatilis, Müller) and Artemia during the enrichment and starvation period. Fish Physiol. Biochem. 2008, 34, 391-404. [CrossRef] [PubMed]

15. Lee, C.-S.; O’Bryen, P.J.; Marcus, N.H. Copepods in Aquaculture, 1st ed.; Blackwell Publishing Ltd.: Oxford, UK, 2005; ISBN 978-0-8138-0066-0.

16. Holt, G.J.; Webb, K.A.; Rust, M.B. Microparticule diets: Testing and evaluating success. In Larval Fish Nutrition, 1st ed.; Holt, G.J., Ed.; John Wiley \& Sons Inc. Publication: Chichester, UK, 2011; pp. 353-372, ISBN 978-0-8138-1792-7.

17. Øie, G.; Reitan, K.J.; Evjemo, J.O.; Støttrup, J.; Olsen, Y. Live feeds. In Larval Fish Nutrition, 1st ed.; Holt, G.J., Ed.; John Wiley \& Sons Inc. Publication: Chichester, UK, 2011; pp. 307-334, ISBN 978-0-8138-1792-7.

18. Naz, M.; Yılmaz, E.; Töre, Y.; Diken, G.; Tanrıverdi, Z.; Tekin, S. Canlı Yemlerin Proteaz Aktivitelerinin Belirlenmesi. In 16. Ulusal Su Ürünleri Sempozyumu; Mustafa, Ü., Deniz, Ç., Eds.; Akdeniz Üniversitesi: Antalya, Turkey, 2011; p. 146.

19. Naz, M.; Yúfera, M. The Potential inhibitory effects of the commercial diets on protease activities of larvae and live foods. J. Fish. Sci. 2012, 6, 224-231. [CrossRef]

20. Haközü, G. Çipura (Sparus aurata, Linneaus 1758) Larvalarının Kortizol Seviyeleri Üzerine Ticari Besleme Prosedürünün Etkileri. Master's Thesis, Department of Aquaculture, Mustafa Kemal Üniversitesi, Hatay, Turkey, 2014.

21. Kassim, Z.; John, A.; Chin, L.K.; Zakaria, N.F.; Asgnari, N.H. Sustainable technique for selected live feed culture. In Sustainable Aquaculture Techniques; Hernandez-Vergara, M.P., Perez-Rostro, C.I., Eds.; InTech: London, UK, 2014; pp. 105-133.

22. Diken, G.; Demir, O.; Naz, M. The potential effects of commercial feeding protocol on protease activities and cortisol stress responses of meagre (Argyrosomus regius). Agric. Food 2016, 4, 460-472.

23. Diken, G.; Demir, O.; Naz, M. Sörvaj dönemi çipura (Sparus aurata Linnaeus, 1758) ve levrek balığ1 (Dicentrarchus labrax Linnaeus, 1758) larvalarının proteaz aktiviteleri üzerine besinlerin etkileri ve fizyolojik durumlarının belirlenmesi. In IV. Balık Besleme ve Yem Teknolojileri Çalıştayı; Çukurova Üniversitesi: Adana, Turkey, 2016; p. 4.

24. Dabrowski, K. The Feeding of Fish Larvae: Present «State of the Art» and Perspectives. Reprod. Nutr. Dév. 1984, 24, 807-833. [CrossRef]

25. Koven, W.; Kolkovski, S.; Hadas, H.; Gamsız, K.; Tandler, A. Advances in the development of microdiets for gilthead seabream, Sparus aurata: A Review. Aquaculture 2001, 194, 107-121. [CrossRef] 
26. Lazo, J.P.; Darias, M.J.; Gisbert, E. Ontogeny of the digestive tract. In Larval Fish Nutrition, 1st ed.; Holt, J.G., Ed.; John Wiley \& Sons Inc. Publication: Chichester, UK, 2011; pp. 5-46, ISBN 978-0-8138-1792-7.

27. Hernández-Cruz, C.M.; Schuchardt, D.; Roo, J.; Borrero, C.; Fernández-Palacios, H. Optimización del protocolo de destete de corvina (Argyrosomus regius, Asso, 1801). In Actas XI Congreso Nacional de Acuicultura; Eiroa, A.C., Díaz, A.G., Acosta, C.P., Eds.; Centro De Investigacións Mariñas De Coron Consellería De Pesca E Asuntos Marítimos Xunta De Galicia: Vigo, Española, 2007; pp. 751-754, ISBN 978-84-611-9086-7.

28. Roo, J.; Hernández-Cruz, C.M.; Borrero, C.; Schuchardt, D.; Fernández-Palacios, H. Effect of larval density and feeding sequence an meagre (Argyrosomus regius; Asso, 1801) larval rearing. Aquaculture 2010, 302, 82-88. [CrossRef]

29. Arda, G. Sarıă̆ı (Argyrosomus regius) Larvalarında Gastrointestinal Tüpün Histolojik Gelişimi. Master's Thesis, Department of Aquaculture, Ege Üniversitesi, İzmir, Turkey, 2011.

30. Gracia, E.P.; Jofre, A.G. Cultivo de esciénidos. I: La corvina. In Diversificación de Especies en la Piscicultura Marina Española Fundación; Martínez, E.A., Atarés, I.A., Eds.; Observatorio Español de Acuicultura Instituto Español de Oceanografía: Madrid, Española, 2013; pp. 117-153.

31. Süzer, C.; Kamacı, H.O.; Çoban, D.; Yıldırım, S..; Fırat, K.; Saka, S. Functional changes in digestive enzyme activities of meagre (Argyrosomus regius; Asso, 1801) during early ontogeny. Fish Physiol. Biochem. 2013, 39, 967-977. [CrossRef] [PubMed]

32. Saavedra, M.; Grade, A.; Candeias-Mendes, A.; Pereiraa, T.G.; Teixeiraa, B.; Yúfera, M.; Conceiçãoc, L.E.C.; Mendesa, R.; Pousão-Ferreira, P. Different dietary protein levels affect meagre (Argyrosomus regius) larval survival and muscle cellularity. Aquaculture 2016, 450, 89-94. [CrossRef]

33. Diken, G.; Demir, O.; Naz, M. Determination of the inhibitory effects of microdiets used in routine commercial feeding protocols on protease activities of Argyrosomus regius (Asso, 1801) larva. Iran. J. Fish. Sci. 2017, 16, 96-107.

34. Diken, G.; Demir, O.; Naz, M. The inhibitory effects of different diets on the protease activities of Argyrosomus regius (Pisces, Scianidae) larvae as a potential candidate species. J. Appl. Anim. Res. 2018, 46, 94-99. [CrossRef]

35. Candeias-Mendes, A.; Castanho, S.; Ribeiro, L.; Conceição, L.E.C.; Dias, J.; Costa, S.; Bandarra, N.M.; Pousão-Ferreira, P. Melhoramento do cultivo larvar de corvina, Argyrosomus regius. In XV Congreso Nacional y I Congreso Ibérico de Acuicultura; Navas, J.I., Cordero, M.L., Cárdenas, S., Eds.; Año de Publicación: Huelva, España, 2015; pp. 536-537.

36. Solovyev, M.M.; Campoverde, C.; Öztürk, S.; Moreira, C.; Diaz, M.; Moyano, F.J.; Estévez, A.; Gisbert, E. Morphological and functional description of the development of the digestive system in meagre (Argyrosomus regius): An integrative approach. Aquaculture 2016, 464, 381-391. [CrossRef]

37. Zambonino, I.J.L.; Cahu, C.L. Ontogeny of the gastrointestinal tract of marine fish larvae. Comp. Biochem. Physiol. Part C 2001, 130, 477-487. [CrossRef]

38. Warner, A.H.; Perz, M.J.; Osahan, J.K.; Zielinski, B.S. Potential role in development of the major cysteine protease in larvae of the brine shrimp Artemia franciscana. Cell Tissue Res. 1995, 282, 21-31. [CrossRef] [PubMed]

39. Yúfera, M.; Fernández-Diaz, C.; Pascual, E.; Sarasquete, M.C.; Moyano, F.J.; Diaz, M.; Alarcom, F.J.; Garcia-Gallego, M.; Para, G. Towards an inert diet for first feeeding gilthead seabream Sparus aurata L. larvae. Aquacult. Nutr. 2000, 6, 143-152. [CrossRef]

40. Warner, A.H.; Shridhar, V. Purification and characterization of a cytosol protease from dormant cysts of the brine shrimp Artermia. J. Biol. Chem. 1985, 260, 7008-7014. [PubMed]

41. Cahu, C.; Zambonino, I.J.L. Substitution of Live Food by Formulated Diets in Marine Fish Larvae. Aquaculture 2001, 200, 161-180. [CrossRef]

42. Zambonino, I.J.L.; Cahu, C.L. Development and response to a diet change of some digestive enzymes in sea bass (Dicentrarchus labrax) larvae. Fish Physiol. Biochem. 1994, 12, 399-408.

43. Cahu, C.L.; Zambonino, I.J.L. Effect of the molecular form of dietary nitrogen supply in sea bass larvae: Response of pancreatic enzymes and intestinal peptidases. Fish Physiol. Biochem. 1995, 14, 209-214. [CrossRef] [PubMed]

44. Moyano, F.J.; Diaz, M.; Alarcon, F.J.; Sarasquete, M.C. Characterization of digestive enzyme activity during larval development of gilthead seabream Sparus aurata. Fish Physiol. Biochem. 1996, 15, 121-130. [CrossRef] [PubMed] 
45. Walter, H.E. Proteinases: Methods with haemoglobin, casein and azocoll as substrates. In Methods of Enzymatic Analysis Volume V Enzymes 3: Peptidases, Proteinases and Their Inhibitors, 3rd ed.; Bergmeyer, H.U., Bergmeyer, J., Graßl, M., Eds.; Verlag Chemie: Weinheim, Germany, 1984; pp. 270-277, ISBN 3-527-26045-5.

46. Bradford, M.M. A rapid sensitive method for the quantitation of microgram quantities of protein utilising the principle of protein-dye binding. Anal. Biochem. 1976, 72, 248-254. [CrossRef]

47. García-Carreño, F.L. Proteinase inhibitors. Trends Food Sci. Technol. 1996, 7, 197-204. [CrossRef]

48. SPSS Inc. SPSS for IBM Version 23.0; SPSS Inc.: Chicago, IL, USA, 2015.

(C) 2019 by the authors. Licensee MDPI, Basel, Switzerland. This article is an open access article distributed under the terms and conditions of the Creative Commons Attribution (CC BY) license (http:/ / creativecommons.org/licenses/by/4.0/). 